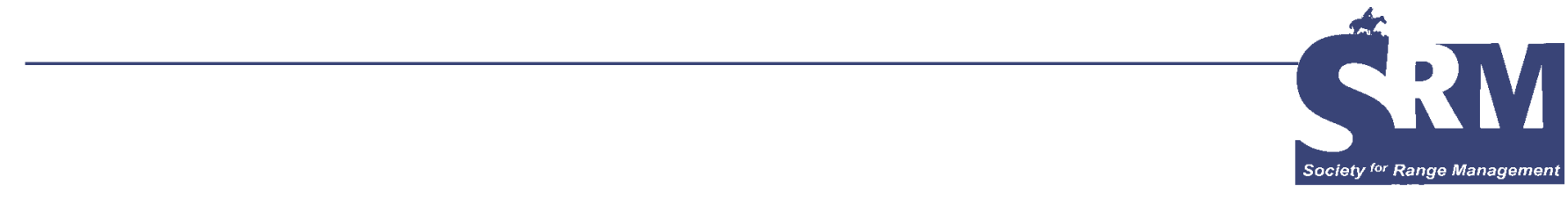

\title{
Students and the SRM
}

\section{By Kimberly Haile}

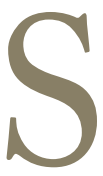

tudent members of the Society for Range Management might find themselves asking the following questions: "What can I do as a young member of the Society for Range Management"? Or "How will being a member of a professional society at a young age help me in the future"? Another question might be "Do the older members and professionals of the Society for Range Management really want me here at their meetings or to become involved with the Society"? And "Where do I fit in this professional society"?

As a student member, I have asked myself these questions. As a member of the SRM, I have participated in activities such as the High School Youth Forum, various contests, and The Student Conclave, and know that the students are an important part of SRM and what it stands for. We just need to find out where we fit and take an active role within the SRM.

As younger members, we can play an important role with in the Society, but we often have problems trying to figure out where we can get involved. There are many ways that students can be involved within SRM; in fact, there might be more activities for a student to get involved in at the annual meeting than there are for a professional. For example, the plant identification competition, Undergraduate Range Management Exam (URME), Range Cup, and undergraduate speaking competition are just a few of these opportunities.

Student Conclave is also available for students to join. The Student Conclave was formed for the professional development of high school and college students who attend the annual meeting. The students are able to meet with other students from across North America and interact with each other at a professional level. I have found this can be quite a learning experience. We not only learn about what others are involved in at their universities but also find out about some of the issues affecting rangelands, be it invasive plants or dealing with the public about land conservation.

At the SRM meeting, I was invited to participate in several committees and found that this is another way that students can get involved. The committees focus on various topics from watershed management to planning activities for the students. The society depends on committees to keep things running smoothly; it is important for students to get involved in the committees. This involvement allows us to learn more about the SRM, and we can work with some of the professional members. We can offer a fresh voice or a different perspective, which can be very beneficial to the committees, as well as to the Society.

As students, we need to start developing professionally, making career contacts, and learning about issues relating to range management. Attending annual meetings, section meetings, and field days can help us with this development. When attending meetings we might be meeting some of our future bosses, coworkers, and/or employees. These professionals are able to help us find the perfect career, advise us for graduate school, and help us with career goals we have set for ourselves. Being up to date on current range issues allows us to make educated decisions about range management while we are still in school and are starting down our career paths.

The older or more experienced members within the society see us as new faces who will take their places one day. They are willing to get to know us and work with us. I have yet to attend any Society for Range Management 
events where one of the long-term members refused to talk and visit with me. As students, we are able to learn something from them and we might be surprised that they can learn something from us. We look at range management and life in a different way than some of the older members. I see range management as a science (about which we are still learning) that is used to conserve a valuable natural resource. We are trained to be stewards of the land that is used for all living beings, be it humans or other living creatures, and we must learn to manage it to meet the goals of everyone who depends on rangelands. I believe that education plays an important role in range management. Through education about the importance of range management for issues such as water quality and possibly reducing wildfires by the use of prescribed burns, we can help the public understand how important range management is to them. This past summer I helped with the Youth Range Workshop in Texas. One night we were discussing the future of the camp and it was mentioned that 10 years from now, livestock will not be a major topic at the camp. Instead, the focus of the camp will be more on the conservation of rangelands or on ways of making money off the land other than livestock production.

We need to remember we are the future of the Society for Range Management. For this organization to keep going we need the young professionals and college-age students to take an active role within the society. By getting involved at a young age, we are developing professionally and are aware of current issues that are facing range conservation and management. I am sure if you ask the older members what they would change about their professional careers, one of the main answers would be getting involved with a professional organization and start networking at a young age. This summer, my boss stated to my coworker and me, "My career is over, yours is just beginning," so do your best get involved and do not wake up and realize your life and career is half-way over and you have not done anything to develop professionally or found the career you truly enjoy waking up to each morning.

Not only are we the future of the Society for Range Management, we are the next leaders and decision makers in conservation and the country in which we live. Therefore, it is important we stay up to date with issues that are facing the country and conservation within the United States and the world.

I end with a quote by Dr Dale Rollins that all of us students must consider: "When opportunity knocks, who will answer?" We have many opportunities available to us within the Society and within the range profession; now it is up to us to answer the call and take an active role.

Author is a student at Texas AE'M, President of the SRM Student Conclave, and a Member of the Rangelands Editorial Board,Bryan, TX 77802, USA, kimberlybaile@neo.tamu.edu. 